\title{
AN OVERVIEW OF BONE REPLACEMENT MATERIALS - BIOLOGICAL MECHANISMS AND TRANSLATIONAL RESEARCH
}

Radomir Šćepanović ${ }^{*}$ and Momir Stevanović ${ }^{*}$

${ }^{1}$ Military Medical Academy, University of Defense, Belgrade, Serbia

${ }^{2}$ University of Kragujevac, Faculty of Medical Sciences, Department of Dentistry, Kragujevac, Serbia

* Both authors equally share the first authorship

\author{
PREGLED MATERIJALA ZA ZAMENU KOŠTANOG TKIVA - BILOŠKI \\ MEHANIZMII I TRANSLACIONA ISTRAŽIVANJA \\ Radomir Šćepanović ${ }^{*}$ i Momir Stevanović ${ }^{*}$ \\ ${ }^{1}$ Vojnomedicinska akademija, Univerzitet odbrane, Beograd, Srbija \\ ${ }^{2}$ Univerzitet u Kragujevcu, Fakultet medicinskih nauka, Odsek za stomatologiju, Kragujevac, Srbija \\ * autori imaju jednak doprinos
}

\begin{abstract}
Bone defects might develop as a result of various pathological entities. Bone grafting is a widely used procedure that involves replacement of the missing tissue with natural or artificial substitute. The idea for artificial replacement of the missing bone tissue has been known for centuries and the evidence for these treatments has been found ever since prehistoric period. Bone grafting has been practiced for centuries with various non-osseous natural materials. The skeletal system plays a crucial role in the structural support, body movement and physical protection of the inner organs. Regeneration of bone defects is crucial for reestablishing of the form and function of the skeletal system. While most bone defects can heal spontaneously under suitable conditions, bone grafts or substitute biomaterials are commonly used therapeutic strategies for reconstruction of large bone segments or moderate bone defect. An ideal bone grafting material should provide mechanical strength, be both osteoinductive and osteoconductive and should provide space for vascularization. In order to overcome limitations associated with the standard treatment of bone grafts, there is an increasing interest in studying substitute biomaterials, made of naturally derived or synthetic materials. Bone substitutes can be derived from biological products or from synthetic materials. Prior to testing in human subjects, the bone substitute materials should be tested in vitro and in vivo using animal models. Establishing of a suitable animal model is an essential step in the investigation and evaluation of the bone graft materials.
\end{abstract}

Keywords: bone grafting, biomaterials, dentistry, orthopedics.

\section{SAŽETAK}

Kao rezultat različitih patoloških entiteta, mogu se razviti oštećenja kostiju. Ugradnja ili kalemljenje kostiju (eng. bone grafting) je široko korišćena procedura koja podrazumeva zamenu nedostajućeg tkiva prirodnom ili veštačkom zamenom. Ideja za veštačko nadoknađivanje nedostajućeg koštanog tkiva poznata je vekovima, a dokazi za ovaj način lečenja pronađeni su još od praistorije. Za zamenu koštanog tkiva vekovima su korišćeni prirodni, nekoštani materijali. Skeletni sistem igra presudnu ulogu u strukturnoj podršci, kretanju tela i fizičkoj zaštiti unutrašnjih organa. Za ponovno uspostavljanje oblika i funkcije koštanog sistema, obnova koštanih defekata je od presudnog značaja. Iako većina koštanih defekata može spontano zaceliti pod odgovarajućim fiziološkim uslovima, za rekonstrukciju velikih koštanih segmenata ili umereni koštani defekt, koriste se koštani graftovi ili supstitutivni biomaterijali. Idealan materijal za kalemljenje kostiju treba da obezbedi mehaničku čvrstoću, da bude i osteoinduktivan i osteokonduktivan, a takođe treba $i$ da obezbedi prostor za vaskularizaciju. Da bi se prevazišla ograničenja koja su povezana sa standardnim tretmanom koštanim transplantatima, postoji sve veće interesovanje za proučavanje zamenskih biomaterijala, napravljenih od prirodno izvedenih ili sintetičkih materijala. Zamene kosti mogu se dobiti iz bioloških proizvoda ili iz sintetičkih materijala. Pre ispitivanja na ljudskim subjektima, biomaterijal za zamenu koštanog tkiva, je prvo potrebno testirati in vitro i in vivo na animalnim modelima. Uspostavljanje odgovarajućeg životinjskog modela je ključni korak u istraživanju i proceni materijala za koštane kaleme.

Ključne reči: graftovi koštanog tkiva, biomaterijali, stomatologija, ortopedija.

\author{
ABBREVIATIONS \\ TGF- $\boldsymbol{\beta}$ - transforming growth factor beta \\ DBM - demineralized bone matrix \\ PRP - platelet-rich plasma \\ HA - hydroxyapatite \\ CaP - calcium phosphate \\ TCP-tricalcium phosphate
}




\section{INTRODUCTION}

Bone grafting is a commonly performed surgical procedure in orthopedics, dentistry and neurosurgery, it is also the second most common transplantation tissue (1). Bone defects might develop as a result of various pathological entities like trauma, infection, tumor and surgery as well (2). Bone grafting is a procedure that involves replacement of the missing tissue with natural or artificial substitute. The idea for replacement of the missing bone tissue has been known for centuries and the evidence for these orthopedic treatments has been found in the Egyptian civilization and even earlier, in prehistoric times (3). The first successful autogenic and allogenic grafts were reported in the $19^{\text {th }}$ century by Van Merren (4). Bone grafting has been practiced for centuries with various non-osseous materials of the natural origin (marble, wood etc.) but with little success. In 1892,Dreesmann from Trendelenburg's Clinic in Bonn, first reported the successful use of plaster of Paris (calcium sulfate) as bone replacement in eight patients (5). Shortly thereafter, this material was investigated in experiments with animals (6)

Bone is a connective tissue with the complex hierarchical architecture. In fact, the bone is a multifaceted organ consisting of several tissues, the cortical bone, the cancellous bone with the marrow compartment and the periosteum (7). Bone remodeling is a permanent process during which bone is permanently rebuilt. The purpose of this process is to assure the bone mineral homeostasis, to regenerate micro fractures, or to adapt the bone to new mechanical load (8). The fine balance between osteoblasts, the cells that form the bone tissue, and osteoclasts, degrading bone macrophages, is essential for the bone metabolism and physiology. The skeletal system plays a crucial role in the structural support, movement and physical protection of the inner organs. Moreover, in addition to the mineral storage, the skeletal system is the site of blood cell generation and differentiation and has important hematopoietic and immunological functions (7). Considering various roles of the bone tissue, regeneration of bone defects is crucial to re-establish the form and function in the body (7).

The healing of bone defect is a time-consuming process of reconstruction of the bone tissue. Due to the regeneration ability of the bone tissue, most bone defects can heal spontaneously under suitable physiological conditions. On the other hand, large defects, also known as critical bone defects, may not heal spontaneously $(9,10)$. The repair of critical bone defects is still clinically challenging, despite the remarkable regenerative capacity of the bone. For reconstruction of large bone segments, or for filling of moderate bone defect, bone grafts or substitute biomaterials are commonly used therapeutic strategies.

\section{BIOLOGIC MECHANISMS OF BONE REGENERATION}

There are four essential mechanisms of bone regeneration underlying bone grafting: osteogenesis, osteoinduction, osteoconduction and osteointegration (11). Osteogenesis or bone formation presents transformation of a preexisting mesenchymal tissue into the bone tissue (12). In the context of bone grafting, it presents the "osteogenic" potential of the graft or the ability of donor graft osteoprogenitor cells to proliferate and differentiate to osteblasts and to contribute to the growth of a new bone $(11,13,14)$. Osteoinduction presents the stimulation and activation of host mesenchymal stem cells or osteoprogenitor cells from the surrounding tissuewhich differentiate into osteoblasts (11). The process of osteoinduction is conducted and mediated by various signals and activation of cellular receptors particularly from TGF- $\beta$ super family (14).

Osteoconduction presents the ability of bone cells, osteoblasts and osteoclasts in the grafting area, to move across a scaffold and slowly replace it with a new bone (15). This property occurs when the bone graft material serves as a scaffold for the new bone growth, which is perpetuated by the native bone (13). An osteoconductive material is one that permits generation of the bone tissue on its surface or down into its structures (16). The material with both features, osteoconductive and osteoinductive, besides its role as a scaffold for currently existing osteoblasts, will also stimulate differentiation of new osteoblasts, promoting faster integration of the graft (13).

The final result in bonding between the host bone and graft is referred as osteointegration. This process is defined as the direct anchorage of an implant by formation of the bony tissue around the implant without growth of the fibrous tissue at the bone-implant interface (16). Recent definition states that it is a "phenomenon where an implant becomes so fused with bone that they cannot be separated without fracture" (17).

\section{TYPES OF BONE SUBSTITUTES}

The bone grafting material should provide mechanical strength, be both osteoinductive and osteoconductive and should provide space for vascularization and tissue infiltration (18). In selection of a graft, some aspects need to be assessed: biologic acceptability, predictability, clinical feasibility, and minimal postoperative sequelae (19). Utilizing bone obtained from the same individual receiving the graft is autologous bone grafting (20). For bone defect restoration, the gold standard is autologous grafting, due to its histocompatibility and non-immunogenic properties (21). Also, autografts provide optimal osteoconductive, osteoconductive, and osteogenic properties (14). However, disadvantages are also numerous. These grafts are associated with a high rate of postoperative complications, such as chronic pain on the donor site or cosmetic disadvantages $(22,23)$. The most frequently chosen bone substitute is allograft, derived from a human, but from an individual other than the one receiving the graft. Allografts are often derived from cadavers and from tissue banks. The use of this type of material is also associated with certain restrictions. Eliciting of the immune response and transmitting various diseases are the most significant limitations (24). Therefore, allografts are prepared using various techniques designed to minimize the host's immune response 
and to reduce the risk of transmission of a disease. However, the preparation methods can significantly weaken the biologic and mechanical properties initially present in the bone tissue $(25,26)$.

There is an increasing interest in studying substitute biomaterials, made of naturally derived or synthetic materials in order to overcome limitations associated with the standard treatment of bone grafts (27). Bone substitutes can be derived from biological products or synthetic materials. Demineralized bone matrix (DBM) is derived from a human bone by acid removal of the mineral matrix, while maintaining the organic matrix and growth factors. DBM is mostly used for filling purposes (28). Platelet-rich plasma (PRP), obtained from a patient's blood is generally used as a supplement to other materials (29).

\section{IN VIVO ANIMAL MODELS IN TRANSLATIONAL RESEARCH}

The bone substitute materials, prior to testing in human subjects, should be tested in vitro and in vivo using animal models. Establishing of a suitable animal model is an essential step in the investigation and evaluation of the bone substitute materials. It should be kept in mind that results obtained from in vivo animal studies often differ in their translatability to the clinical condition (33).
Hydroxyapatite (HA) is the primary mineral component of teeth and bone tissue. It has slow resorption and very good mechanical properties. This material is available in natural and synthetic form and it can be used alone or as a part of some composite materials (28). Considering synthetic bone substitutes, calcium sulfate, as mentioned before, was introduced in 1892 (5). Nevertheless, this material has only recently been accepted for general use (30). Although its use has some advantages such as its similarity to the bone and osteoconductivenes, it also shows some disadvantages, fast resorption and absence of osteoinductivety and osteogenicity, as well as relatively common local complications (31). Synthetic scaffolds made from calcium phosphate are ceramics and they have been widely used in dentistry and in orthopedics for a few decades (32).

For the selection of a specific animal species as a testing model, various factors have to be considered. Most importantly, the chosen animal model should clearly demonstrate analogies in comparison to humans, both physiological and pathophysiological. Small animals, such as rodents, are suitable for the investigation of pathophysiology and pathogenesis, and large animals are often used to study long-term diseases processes and treatment options (Table 1) (8).

Table 1. Animal models characteristics in bone defect studies

\begin{tabular}{|c|c|c|c|}
\hline Animal species & $\begin{array}{l}\text { Bone defect to- } \\
\text { pography }\end{array}$ & Advantages & Disadvantages \\
\hline Rodents & $\begin{array}{l}\text { Femur } \\
\text { Calvaria }\end{array}$ & $\begin{array}{ll}\text { - } & \text { small size } \\
\text { - } & \text { easy to handle } \\
\text { - } & \text { suitable life span } \\
\text { - } & \text { cost }\end{array}$ & $\begin{array}{l}\text { - } \quad \text { small-sized long bones } \\
\text { - thin and fragile cortices } \\
\text { - } \quad \text { absent Haversian-type remodelling in } \\
\text { the cortex }\end{array}$ \\
\hline Pig & Craniofacial & $\begin{array}{l}\text { - } \quad \text { bone anatomy } \\
\text { - } \quad \text { healing capacity, } \\
\text { - } \quad \text { remodelling similar to hu- } \\
\text { mans; } \\
\text { - } \quad \text { similar bone mineral density } \\
\text { and concentration } \\
\text { - } \quad \text { lamellar bone structure }\end{array}$ & $\begin{array}{l}\text { - } \text { denser trabecular network } \\
\text { - } \text { difficult to handle } \\
\text { - } \quad \text { shorter tibiae and femur } \\
\text { - } \quad \text { large growth rates } \\
\text { - } \quad \text { very high body weight }\end{array}$ \\
\hline Sheep & Tibiae & $\begin{array}{l}\text { - body weight similar to adult } \\
\text { humans } \\
\text { - } \text { easy to handle }\end{array}$ & 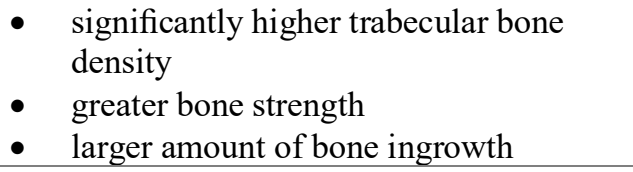 \\
\hline Rabbit & $\begin{array}{l}\text { Tibiae } \\
\text { Femur }\end{array}$ & $\begin{array}{ll}\text { - } & \text { easy to handle } \\
\text { - } & \text { small size } \\
\text { - } & \text { early skeletal } \\
\text { - } & \text { maturity }\end{array}$ & $\begin{array}{l}\text { - } \\
\text { - } \\
\text { - } \\
\text { differences in bone anatomy, } \\
\text { faster skeletal change and bone turnover }\end{array}$ \\
\hline
\end{tabular}

Adapted from: Li et al (9) 
Rodents are one of the most commonly used animal models in testing biomaterials as bone substitutes and regeneration of the bone tissue (34). These mammals are mostly used for the age-related metabolic and regenerative studies of the bone tissue since their bone biology is strongly dependent on the age and gender (35). However, there are obvious limitations in using rodent models. Rodents have small-sized long bones and thin and fragile cortices and trabecular bone content is limited (36). Also, Haversian remodeling does not occur in these animals (34). Bearing in mind all the shortcomings, rodents are nevertheless, widely used in studies of the bone substitute materials, mostly as a model of critical-size defects, the smallest wounds established intraosseously, which cannot heal spontaneously during the lifetime of the animal (37). Preclinical testing of the bone replacement materials is also broadly performed in large skeletal animals including pigs, dogs, goats and sheep. The bone tissue structure and composition of these animals is highly similar to those of humans (38). In preclinical studies focused on the processes which are related to the body size or metabolic characteristics, like biomechanics, the species of experimental animals should be as close to human as possible (39). Sheep and goats are suitable for testing the human implants and prostheses due to their body weight and long bones (40). Although their bones have macrostructure similar to human, in sheep, bone consists predominantly of the primary bone structure unlike humans and they have significantly higher bone densities compared to the human bone (41). Regardless of the observed differences in the bone microstructure, studies reported that sheep exhibit similar bone remodeling compared to human (42). The sheep tibia defect model has been widely used to test the bone substitute materials in the bone regeneration $(43,44)$.

Regarding the bone anatomy, morphology, metabolism and mineral density, pigs are considered to be close representative models of the human bone investigations $(45,46)$. Also, histology of the bone tissue and lamellar bone structure is similar to that of humans (47). Disadvantages of this animal model refer to the length of tibiae and femora in pigs, which is relatively small and therefore unsuitable for the implant studies. Also, high body weight makes them unsuitable for the orthopedic research (9). On the other hand, the craniofacial bone defect model is used widely for testing the bone substitute biomaterials in these animals (9).

\section{ADVERSE EFFECTS OF BONE REPLACEMENT MATERIALS}

The application of the bone replacement biomaterials causes a cascade of reactions in the biological environment. The biocompatibility and longevity of the grafts are determined by the host tissue, together with the physical and chemical properties of biomaterials. Adverse reactions to the graft in the body may be diverse and include foreign body reactions, chronic inflammation, infections, hypersensitivity reactions etc. (48). Also, biomaterials can potentially induce a toxic effect to the host tissues, in terms of the acute toxicity of the material itself or to the chronic toxicity due to the material wear over time. The replacement biomaterials may release over time, fine debris particles and the chronic effects of these particles, in terms of the local and systemic toxicity become the major criteria in the toxicity evaluation (49). Preclinical studies, prior to the clinical use, should investigate various aspects of the long term impact of graft materials on the host tissue, such as cytotoxicity, genotoxicity, systemic acute, sub acute and chronic toxicity and carcinogenicity. For instance, in vivo studies of calcium phosphate $(\mathrm{CaP})$ compounds, the material widely used in the regenerative clinical treatments, demonstrated that release of nanosized $\mathrm{CaP}$ may have a chronic hepatotoxic effect (50). Furthermore, nanoTCP particles incorporated into rabbit tibial defects elicited an excessive and prolonged inflammatory response associated with the decreased bone regeneration (51). A recent study demonstrated that the long term administration of hydroxyapatite or tricalcium phosphate nano particles had a significant prodepressant effect in rodents. Also, a prolonged treatment with amorphous calcium phosphate also resulted in a significant decline in cognitive functions, and these adverse effects were accompanied by the increased oxidative damage and apoptosis in the prefrontal cortex (52).

\section{REFERENCES}

1. Giannoudis PV, Dinopoulos H, Tsiridis E. Bone substitutes: an update. Injury 2005; 36(3): S20-7.

2. Poirier, J., Ribadeau Dumas, J.L., Catala, M., et al. Histologie: les tissus. (2002). Médecine 1ere année. 2eme éd. Paris: Masson, 2002

3. Donati D, Zolezzi C, Tomba P, Viganò A. Bone grafting: historical and conceptual review, starting with an old manuscript by Vittorio Putti. Acta Orthop. 2007; 78(1): 19-25.

4. Fernandez de Grado G, Keller L, Idoux-Gillet Y, Wagner Q, Musset AM, Benkirane-Jessel N, et al. Bone substitutes: a review of their characteristics, clinical use, and perspectives for large bone defects management. J Tissue Eng. 2018; 9: 2041731418776819.

5. Dressman H. Ueber Knochenplombierung bei Hohlenformigen Defekten des Knochens. Beitr Klin Chir 1892. 9, 804-10.

6. Martin E. Zur AiisfuIIune von Knochenhohlen mit todtem Material. Zentralbl. Cbir. 1894; 2 I : I 93200.

7. McGovern JA, Griffin M, Hutmacher DW. Animal models for bone tissue engineering and modelling disease. Dis Model Mech 2018; 11(4): dmm033084.

8. Gabriele Sommer, N., Hahn, D., Okutan, B., Marek, R., \& Weinberg, A.-M. (2020). Animal Models in Orthopedic Research: The Proper Animal Model to Answer Fundamental Questions on Bone Healing Depending on Pathology and Implant Material ( $1^{\text {st }}$. ed.). Animal Models in Medicine and Biology. Eva Tvrdá and Sarat Chandra Yenisetti, IntechOpen.

9. Li Y, Chen SK, Li L, Qin L, Wang XL, Lai YX. Bone defect animal models for testing efficacy of bone substitute biomaterials. J Orthop Translat 2015; 3(3): 95-104. 
10. Clements JR, Carpenter BB, Pourciau JK. Treating segmental bone defects: a new technique. J Foot Ankle Surg 2008; 47(4): 350-6.

11. Giannoudis PV, Dinopoulos H, Tsiridis E. Bone substitutes: an update. Injury 2005; 36(3): S20-7.

12. Gilbert SF. (2000). Developmental Biology. 6th edition. Sunderland (MA): Sinauer Associates; Available from: https://www.ncbi.nlm.nih.gov/books/NBK9983/.

13. Saima S, Jan SM, Shah AF, Yousuf A, Batra M. Bone grafts and bone substitutes in dentistry. J Oral Res Rev 2016; 8(1): 36-8.

14. Cypher TJ, Grossman JP. Biological principles of bone graft healing. J Foot Ankle Surg. 1996; 35(5): 413-7.

15. Wypych G. (2018) Functional fillers - Chemical Composition, Morphology, Performance, Applications $\left(1^{\text {st }}\right.$. ed.). Functional Fillers. ChemTec Publishing, 153-79.

16. Albrektsson T, Johansson C. Osteoinduction, osteoconduction and osseointegration. Eur Spine J 2001; 10(2): S96-101.

17. Hudecki A, Kiryczyński G, Łos MJ. Biomaterials, Definition, Overview. Stem Cells and Biomaterials for Regenerative Medicine 2019; 85-98.

18. Liu X, Ma PX. Polymeric scaffolds for bone tissue engineering. Ann Biomed Eng 2004; 32(3): 477-86.

19. Schallhorn RG. Present status of osseous grafting procedures. J Periodontol 1977; 48(9): 570-6.

20. Kumar P, Vinitha B, Fathima G. Bone grafts in dentistry. J Pharm Bioallied Sci 2013; 5(1): S125-7.

21. Bauer TW, Muschler GF. Bone graft materials. An overview of the basic science. Clin Orthop Relat Res 2000; 371: 10-27.

22. Dodd CA, Fergusson CM, Freedman L, Houghton GR, Thomas D. Allograft versus autograft bone in scoliosis surgery. J Bone Joint Surg Br 1988; 70(3): 431-4.

23. Summers BN, Eisenstein SM. Donor site pain from the ilium. A complication of lumbar spine fusion. J Bone Joint Surg Br 1989; 71(4): 677-80.

24. Friedlaender GE, Strong DM, Tomford WW, Mankin HJ. Long-term follow-up of patients with osteochondral allografts. A correlation between immunologic responses and clinical outcome. Orthop Clin North Am 1999; 30(4): 583-8.

25. Damien CJ, Parsons JR. Bone graft and bone graft substitutes: a review of current technology and applications. J Appl Biomater 1991; 2(3): 187-208.

26. Goldberg, V.M., Stevenson, S. \& Shaffer, J.W. Biology of autografts and allografts. In: Friedlander GE, Goldberg VM, editors. Bone and cartilage allografts: biology and clinical applications. Park Ridge, Illinois: The American Academy of Orthopaedic Surgeons; 1991: $3-11$.

27. Hubbell JA. Biomaterials in tissue engineering. Biotechnology (N Y). 1995; 13(6): 565-76.

28. Campana V, Milano G, Pagano E, Barba M, Cicione C, Salonna G, et al. Bone substitutes in orthopaedic surgery: from basic science to clinical practice. J Mater Sci Mater Med 2014; 25(10): 2445-61.

29. Albanese A, Licata ME, Polizzi B, Campisi G. Plateletrich plasma (PRP) in dental and oral surgery: from the wound healing to bone regeneration. Immun Ageing 2013; 10(1): 23.

30. Chai F, Raoul G, Wiss A, Ferri J, Hildebrand HF. Bone substitutes: Classification and concerns. Rev Stomatol Chir Maxillofac 2011; 112(4): 212-21.

31. Liodaki E, Kraemer R, Mailaender P, Stang F. The Use of Bone Graft Substitute in Hand Surgery: A Prospective Observational Study. Medicine (Baltimore) 2016; 95(24): e3631.

32. Bohner M. Calcium orthophosphates in medicine: from ceramics to calcium phosphate cements. Injury 2000; 31(4): 37-47.

33. Wendler A, Wehling M. The translatability of animal models for clinical development: biomarkers and disease models. Curr Opin Pharmacol 2010; 10(5): 601-6.

34. Gomes PS, Fernandes MH. Rodent models in bone-related research: the relevance of calvarial defects in the assessment of bone regeneration strategies. Lab Anim 2011; 45(1): 14-24.

35. Hambright WS, Niedernhofer LJ, Huard J, Robbins PD. Murine models of accelerated aging and musculoskeletal disease. Bone 2019; 125: 122-7.

36. An, Y.H. \& Freidman, R.J. (1998). Animal models in orthopedic research $\left(1^{\text {st }}\right.$ ed.). Boca Raton, FL: CRC Press 1998. pp. 39-57. 622 p.

37. Schmitz JP, Hollinger JO. The critical size defect as an experimental model for craniomandibulofacial nonunions. Clin Orthop Relat Res 1986; (205): 299-308.

38. Pearce AI, Richards RG, Milz S, Schneider E, Pearce SG. Animal models for implant biomaterial research in bone: a review. Eur Cell Mater 2007; 13: 1-10.

39. An, Y.H. \& Freidman, R.J. (1998). Animal Selections in Orthopaedic Research ( $1^{\text {st }}$ ed.). Florida, US: CRC Press 1998 ; pp. 126-164. 622 p.

40. Newman E, Turner AS, Wark JD. The potential of sheep for the study of osteopenia: current status and comparison with other animal models. Bone 1995; 16(4): 277S$284 \mathrm{~S}$.

41. V DK Development of bone G. Sumner-Smith (Ed.), Bone in clinical orthopedics, W.B. Saunders Co., Philadelphia (2006), pp. 1-80

42. Pastoureau P, Arlot M, Caulin F, Barlet J, Meunier P, Delmas P. Effects of oophorectomy on biochemical and histological indices of bone turnover in ewes. J Bone Miner Res 1989; 4(1): 58.

43. Maissen O, Eckhardt C, Gogolewski S, Glatt M, Arvinte T, Steiner A, Rahn B, Schlegel U. Mechanical and radiological assessment of the influence of rhTGFbeta-3 on bone regeneration in a segmental defect in the ovine tibia: pilot study. J Orthop Res 2006; 24(8): 1670-8.

44. Reichert JC, Epari DR, Wullschleger ME, Saifzadeh S, Steck R, Lienau J, Sommerville S, Dickinson IC, Schütz MA, Duda GN, Hutmacher DW. Establishment of a preclinical ovine model for tibial segmental bone defect repair by applying bone tissue engineering strategies. Tissue Eng Part B Rev 2010; 16(1): 93-104.

45. Thorwarth M, Schultze-Mosgau S, Kessler P, Wiltfang $\mathrm{J}$, Schlegel KA. Bone regeneration in osseous defects 
using a resorbable nanoparticular hydroxyapatite. J Oral Maxillofac Surg 2005; 63(11): 1626-33.

46. Aerssens J, Boonen S, Lowet G, Dequeker J. Interspecies differences in bone composition, density, and quality: potential implications for in vivo bone research. Endocrinology 1998; 139(2): 663-70.

47. Mosekilde L, Kragstrup J, Richards A. Compressive strength, ash weight, and volume of vertebral trabecular bone in experimental fluorosis in pigs. Calcif Tissue Int 1987; 40(6): 318-22.

48. Pecquet Goad ME, Goad DL. Biomedical Material and Devices. Haschek and Rousseaux's Handbook of Toxicologic Pathology 2013; 2: 783-806.

49. Thrivikraman G, Madras G, Basu B. In vitro/In vivo assessment and mechanisms of toxicity of bioceramic materials and its wear particulates. RSC Adv 2014; 4(25): 12763.

50. Liu LP, Xiao YB, Xiao ZW, Wang ZB, Li C, Gong X. Toxicity of hydroxyapatite nanoparticles on rabbits. Journal of hygiene research 2005; 34(4): 474-6.

51. Ooi JP, Kasim SR, Shaari RB, Saidin NA. In vivo efficacy and toxicity of synthesized nano- $\beta$-tricalcium phosphate in a rabbit tibial defect model. Toxicol Res Appl 2018; 2: 1-9.

52. Arsenijevic N, Selakovic D, Katanic Stankovic JS, Mihailovic V, Mit52.rovic S, Milenkovic J, et al. The Beneficial Role of Filipendula ulmaria Extract in Prevention of Prodepressant Effect and Cognitive Impairment Induced by Nanoparticles of Calcium Phosphates in Rats. Oxid Med Cell Longev 2021; 2021: 6670135. 